\title{
THE DIAGNOSTIC VALUE OF THE EXAMINATION OF THE CEREBROSPINAL FLUID
}

\author{
By J. N. Cumings, M.D., M.R.C.P.
}

Lumbar puncture is in most diseases safe but somewhat uncomfortable to the patient, yet while examination of the cerebrospinal fluid (C.S.F.) frequently yields most valuable aid to clinical diagnosis, there are many occasions when such examinations are disappointing. It seems best to limit discussion to specific diseases in which assistance to the clinician can be given by the pathologist.

\section{Normal Cerebrospinal Fluid}

Before turning to the findings in various diseases it is necessary to be certain of the normal range and of the alterations that may occur naturally, for example as a result of increasing age. Table I gives the ranges that are commonly accepted for most of the substances examined.

The exact figure for chlorides may depend to some extent on the blood chloride level, but the sugar level does not vary greatly from one time of the day to another as raised blood sugar levels following a carbohydrate meal are hardly reflected at all in the fluid, and when they are there is a considerable time lag. Even so it is best to try to take C.S.F. at about the same time if one patient is being followed from day to day.

Age affects the findings particularly in relation to protein content. Subjects of 60 or over very frequently show figures of up to 55 or $60 \mathrm{mg}$./ 100 $\mathrm{ml}$., whereas children under ro frequently have only $15 \mathrm{mg}$./ $100 \mathrm{ml}$. in the fluid and there is a corresponding variation between these ages. Prolonged immobility in bed also tends to raise the protein content. The other substances commonly examined show little variation due to these causes.

\section{The C.S.F. in Disease}

\section{Syphilis-Acquired}

Primary. A small proportion (Io to 20 per cent.) of patients with primary syphilis have been shown to have a positive Wassermann and a lymphocytosis in the fluid, but following adequate treatment only a very few retain these abnormalities. Such patients should still be treated and the vast majority will finally show no abnormality.
Secondary. An increase of cells of up to 50 per $\mathrm{cmm}$. composed of lymphocytes, a raised protein of up to $100 \mathrm{mg}$./100 $\mathrm{ml}$. and a positive Wassermann are not uncommon. The Lange in these patients shows a mid-zone curve. Treatment usually removes these abnormalities. Occasionally, a spinal block from an arachnoiditis may be found with a fluid similar to that seen in a block from a spinal tumour, but showing in addition a pleocytosis and a positive Wassermann.

Tertiary. Although three common types of disease involving the central nervous system are seen-a meningo-vascular lesion, tabes and general paralysis of the insane-yet other varieties of affection are possible, but these latter do not usually show any absolute diagnostic features ited the C.S.F.

Table 2 gives in brief the type of results that are usually found in each of these three conditions, with the chief distinguishing features such as type of cell and frequency of positivity of the Wassermann, together with the relative degree of positivity in blood and C.S.F. indicated respectively by the figures in brackets and the number of + signs.

Not every patient shows such clear-cut results at the first fluid examination. The Lange in particular does not always conform to these findings, and paretic curves such as 5544332100 can be seen in meningo-vascular disease. Should such findings persist despite treatment, general paralysis of the insane must be seriously considered, as such curves will change to mid-zone or luetic curves in treated cases of tabes and meningovascular syphilis, but not in general paralysis of the insane. The Wassermann reaction in the fluid is much more easily influenced in meningo-vascular disease than it is in the blood; whereas in tabes and general paralysis of the insane prolonged treatment lowers the Wassermann levels in both blood and fluid much more slowly. In general paralysis of the insane an abnormal Lange curve and positive blood Wassermann may be found after prolonged treatment, even though the fluid Wassermann has become negative.

The Wassermann reaction is only positive in the 
C.S.F. in syphilitic conditions, but a negative test does not exclude syphilis, and a fluid showing all the other findings, even with a negative Wassermann, only rarely occurs in other diseases. The exceptions to this that have been seen are in meningeal spread of a secondary carcinoma, in torulosis, rarely in disseminated sclerosis and in sarcoidosis.

\section{Syphilis-Congenital}

Some patients show no fluid changes. Cases of general paralysis of the insane usually show a slight pleocytosis, slight protein rise, a positive Nonne Apelt test and a Lange of paretic type with a positive Wassermann. These findings are often difficult to alter by treatment or at the best only show slow improvement.

\section{Poliomyelitis}

It is generally agreed that the fluid differs at varying stages of the disease and the usual findings are given in Table 3 .

The particular features to note are that the cells decrease and the protein increases during paralysis. Should the protein be sufficiently raised (e.g. over I $50 \mathrm{mg} . / 100 \mathrm{ml}$.) then a fine coagulum may form, such as is seen in tuberculous meningitis. The differential diagnosis from this latter disease is that in poliomyelitis the sugar and chlorides are normal at all stages. Polymorphs do not occur in the pleocytosis of encephalitis, but are seen in about a quarter of the cases of poliomyelitis until towards the end of the first week of paralysis, after which time only lymphocytes are present. It is not easy by an examination of the C.S.F. to distinguish some cases of poliomyelitis from some forms of benign lymphocytic meningitis. Here there may be a slight reduction in chlorides, a lymphocytic pleocytosis and a raised protein content in the fluid fairly early in the disease. Nevertheless, it is rare to see a patient with lymphocytic meningitis in such an early stage as one may in poliomyelitis, e.g. before paralysis, so that the clinical picture answers the problem except in those cases of poliomyelitis without paralytic signs.

\section{Encephalitis}

The C.S.F. during the active stage is frequently under raised pressure. The fluid is clear and colourless and there is never a coagulum. Cells are increased and are always lymphocytes, together with a few mononuclears in a small number of patients. Protein is only very slightly raised with usually a negative Nonne Apelt test. While the chloride level is normal, the glucose content may frequently be raised. The Lange is frequently abnormal and, while a luetic type is the morê common, paretic curves do occur.

Patients with inclusion body encephalitis show⿳亠口冋 a normal fluid apart from the Lange which is. paretic in type.

In post encephalitic cases changes in the fluid? are not seen, apart from slight protein increase and perhaps a very low luetic type Lange.

\section{Meningitis}

There are three main sub-groups to be discussed which, according to their aetiology, can be des- $\overrightarrow{0}$ cribed as pyogenic, tuberculous or virus meningitis.

Although the first of these is not quite so $\vec{w}$ commonly seen now as formerly, the findings in the C.S.F. can be recorded as in Table 4 .

Exáct figures are, of course, impossible to give 3 . as they depend on the length of infection and the severity of the condition. However, the important features are that in pyogenic conditions the polymorphs outnumber the lymphocytes in theo cell count, whereas the reverse is usually, but not ${ }_{0}$ invariably, true in tuberculous meningitis. Sugar is absent or almost absent in pyogenic cases, but in $\vec{Z}$ tuberculous meningitis there is only a reduction ino amount and no alteration is seen in virus meningitis.

The finding of the responsible organism naturally the most important single diagnostici $\mathbb{D}$ feature. It should and can be found in neares $\overrightarrow{0}$ every case of tuberculous meningitis-by guinea N pig inoculation if necessary-but in practice have not failed to demonstrate it if sufficient fluid (e.g. $8 \mathrm{ml}$.) and time are used; even in one case of a small child with only 12 cells one organism was seen after a prolonged search, and post-mortem $\frac{0}{\square}$ revealed the diagnosis as correct.

It cannot be too frequently stated that the sugar $\overrightarrow{\overrightarrow{0}}$ content of the C.S.F. is the surest guide to prognosis. Given a rising sugar level, whatever the cell, protein or chloride estimations, the patient is

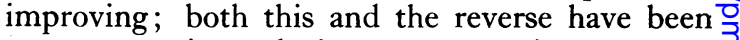
seen many times during streptomycin treatment alone, as well as in cases shown me in Zurich 3 under continuous P.A.S treatment together with streptomycin.

It must always be remembered that intrathecal streptomycin in tuberculous meningitis almost invariably gives rise to an increase in cells and $\frac{D}{0}$ protein, so that no prognostic significance can be placed on results of the examination of the fluid as $N$ regards these two components. It has, moreover, $N$ been recently shown that streptomycin itself in no N way affects the sugar level of the fluid.

The differential diagnosis between virus meningitis and poliomyelitis is very difficult when $\stackrel{0}{\frac{1}{D}}$ no paralysis is present in the latter condition, as has already been mentioned.

.Another difficulty that arises is in sarcoidosis. 


\section{DIAGNOSTIC VALUE OF EXAMINATION OF CEREBROSPINAL FLUID}

TABLE I

Normal Cerebrospinal Fluid

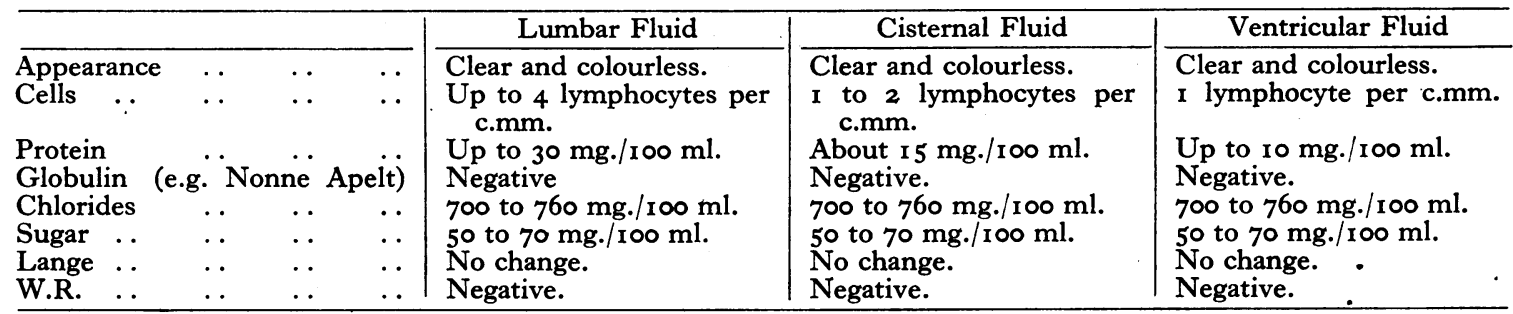

TABLE 2

The C.S.F. IN Syphilis

\begin{tabular}{|c|c|c|c|c|c|}
\hline & & & Meningo-Vascular & Tabes & G.P.I. \\
\hline es & $\ldots$ & $\cdots$ & + & $+\bullet$ & + \\
\hline nce & $\cdots$ & $\ldots$ & Clear and colou & colo & Cles \\
\hline Cells & .. & . & 20 to 150 per c.mm. & & \\
\hline Type of Cell & . . & . & $\begin{array}{l}\text { Mostly lymphocytes, few } \\
\text { large mononuclears. }\end{array}$ & $\begin{array}{l}\text { ocytes, a few large } \\
\text { onuclears. }\end{array}$ & $\begin{array}{l}\text { Usually lymphocytes and } \\
\text { large mononuclears. }\end{array}$ \\
\hline Protein & . & . & $\begin{array}{l}\text { Usually less than } 100 \\
\mathrm{mg} . / \mathrm{r} 00 \mathrm{ml} .\end{array}$ & $\begin{array}{l}\text { Usually under 100 mg./100 } \\
\text { ml. }\end{array}$ & 50 to $150 \mathrm{mg} \cdot / 100$ \\
\hline e Apelt ? & Test & $\cdots$ & to & ++ & ++ \\
\hline Lange & . & . & Variable but usually mid-zone. & Luetic, i.e. mid-zone. & Paretic, i.e. Ist \\
\hline $\begin{array}{l}\text { R. C.S.F. } \\
\text { Blood }\end{array}$ & $\begin{array}{l}\cdots \\
\cdots\end{array}$ & $\cdots$ & $\begin{array}{c}+ \\
++\end{array}$ & $\begin{array}{l}+- \\
+-1\end{array}$ & +++ (in roo \\
\hline
\end{tabular}

Table 3

C.S.F. in Poliomyelitis

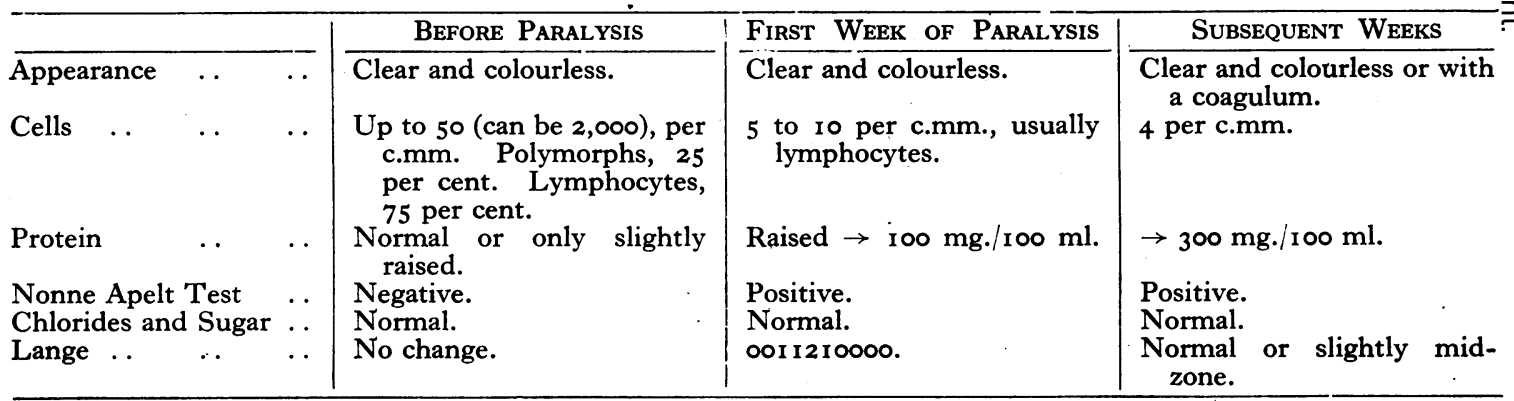

TABLE 4

C.S.F. in Meningitis

\begin{tabular}{|c|c|c|c|c|c|}
\hline & & & Pyogenic & T.B. & Virus \\
\hline Pres & . & 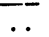 & Raised ++ & Raised ++ & rease. \\
\hline & . & $\cdots$ & Turbid in varying degree. & or slightly & Us \\
\hline $\mathrm{Cel}$ & . & . & Hundreds or thousands. & Tens or hundreds. & sionally \\
\hline of Cell & . & .. & Polymorphs. & $\begin{array}{l}\text { Usually more lymphocytes } \\
\text { than polymorphs ( } 2 \text { or } 3\end{array}$ & Lympl \\
\hline ro & .. & $\cdots$ & $100+\mathrm{mg} . / 100 \mathrm{ml}$. & $100+\mathrm{mg} / 100 \mathrm{ml}$ & $\mathrm{Up}$ to $150 \mathrm{mg} / / 100 \mathrm{ml}$. \\
\hline n & $\cdots$ & . & Positive. & Pos & Posi \\
\hline $\mathrm{Ch}$ & $\cdots$ & $\ldots$ & $\begin{array}{l}\text { Decreased to about } 650 \\
\mathrm{mg} . / 100 \mathrm{ml} .\end{array}$ & $\begin{array}{l}\text { Decreased to } 600 \text { to } 650 \\
\mathrm{mg} . / 100 \mathrm{ml} .\end{array}$ & $\begin{array}{l}\text { Slight decrease-680 mg./ } \\
\text { I00 ml. }\end{array}$ \\
\hline Sugar .. & $\cdots$ & .. & Absent. & $\begin{array}{l}\text { Decreased to } 20 \text { to } 35 \mathrm{mg} . / \\
\text { I00 } \mathrm{ml} \text {. }\end{array}$ & Normal. \\
\hline near & $\cdots$ & .. & ganism. & T.B. & \\
\hline$\ldots$ & $\cdots$ & $\cdots$ & Causal organism. & T.B. & Sterile. \\
\hline
\end{tabular}


Two or three cases have been seen and all showed a fluid similar to that seen in tuberculous meningitis, except that the sugar was never decreased to such a low level and tubercle bacilli were never found. Post-mortem alone revealed the truth, for in one case a negative Kveims test was also obtained.

No verified case of torulosis has been seen, but here the sugar is not greatly reduced and the organism should be found or cultured.

\section{Cerebral Abscess}

A really deep-seated abscess may give no more changes in the C.S.F. than may a similarly sited tumour. This type of abscess is rare and oedema is common around an abscess, hence it is usual to find a raised protein level. A moderate pleocytosis is about half as common as a raised protein and the cells are usually lymphocytes, although polymorphs are not infrequently seen in small numbers. When the abscess is near the ventricular surface a considerable increase in cells, especially in polymorphs, is present. Fluids from such cases also show a lowered sugar and chloride content, but the more chronic abscess with few cells gives rise to little depression in the levels of sugar, and chloride levels in such cases are frequently unaltered. It is uncommon to find organisms in the fluid.

\section{Cerebral Tumour}

The value of examination of the C.S.F. is limited in tumours of the brain, and this is reflected in the fact that one-tenth of the number of lumbar fluids from such cases are now examined as compared with the years before the last war. However, when lumbar puncture is performed there is in many cases either a high normal or a raised C.S.F. pressure. Frequently pressure figures of 200 to $300 \mathrm{~mm}$. are found. Examination of the fluid reveals a raised cell count in about Io per cent. of cases, with a raised protein level in some 80 per cent. of cases. Very occasionally tumour cells can be found. Raised cell counts are found in tumours in close apposition to the ventricles or at the base of the brain. Such patients also show increased protein and while malignant gliomata are more commonly associated with higher figures than the more innocent cerebral tumours, this is not always true, the pontine glioma is a typical exception.

Neurofibromata of the eighth cranial nerve are almost invariably associated with a high protein content and not infrequently the C.S.F. is xanthochromic in appearance. Secondary carcinomatous deposits in the brain frequently show a raised protein and this is rather more common than in malignant gliomata as there is not uncommonly more oedema around the former than the latter.
The value of the examination of the fluid from the lateral ventricles is now well recognized. $A_{z}^{\varrho}$ raised protein content in the fluid from one side $\$$ as compared with the other is an almost sure $c$ indication that the side of the tumour is the same as that of the raised protein level.

\section{Spinal Tumour}

Manometry is of vital importance here. The usual Queckenstedt test is adequate and an absence of any significant rise in the lumbar ${ }^{\infty}$ manometer on jugular compression is indicative of: a spinal block above the level of the puncture. $\overrightarrow{\vec{H}}$ When the block is incomplete there may be a slow and partial rise followed by a similar slow fallFrequently the actual pressure may be as low as 3 . $40 \mathrm{~mm}$. The fluid is rarely yellow and as rarelyin clots spontaneously. Cells are not usually in $-\dot{\omega}$ creased, but in meningeal sarcomatosis, or wide-N spread meningeal tumours there may be a slightion pleocytosis. Protein is always raised in complete block and figures as high as $1,000 \mathrm{mg}$./100 ml. are to be seen. There is practically always some in crease in protein in any spinal tumour whether $Z$ there is a block or not.

The examination of the cisternal fluid is of valare as the protein in this fluid will be normal in many cases of spinal tumour. However, as there may $\frac{8}{8}$ increased protein in the fluid just above a tumour a cervical tumour may give rise to an increasid cisternal fluid protein, but even so there is almosto always a wide disparity between the protein levels in the two regions. Similarly, a raised protein level in the fluid from the lumbar region may be found above a herniated lumbar disc or a lowe? lumbar chondroma.

\section{Disseminated Sclerosis}

Characteristic changes can be found in the fluid in this condition. The acute phases give rise to $\mathbb{X}$. slight to moderate pleocytosis in which the pres dominating cell is the lymphocyte. In some 5 pe? cent. of cases polymorphs in small numbers arê present. The protein content is only very slightly raised above the normal and, in fact, almost neve? exceeds $100 \mathrm{mg}$./100 ml. Globulin is always it excess and an abnormal Lange curve is very fre quently seen. The paretic curve in associations with a raised cell count, slight rise in protein and a negative Wassermann is seen but only occurs in some I 5 per cent. of all cases, whereas the luetic type of curve is seen in some 30 to 40 per cent. 哦 all cases, while some 40 per cent. of all cases show no appreciable change in the Lange.

The C.S.F. in neuromyelitis optica may show $\stackrel{\stackrel{\rho}{w}}{q}$ changes similar to those found in disseminate 
sclerosis, but on the whole cells and protein tend to be higher provided the lumbar puncture is performed in the acute stages.

There are many other diseases in which the C.S.F. is examined but in which there are few, if any, diagnostic features. The one obvious exception to this is in subarachnoid haemorrhage where a fluid intimately mixed with blood is found. Should the haemorrhage be three or more days old the supernatant fluid, after centrifugation, may be pale yellow and after one week the red cells diminish or may be entirely lost, but the yellow colouration may persist along with a slightly raised protein content.

The description given here of the results of the examination of the cerebrospinal fluid has of necessity an air of dogmatism about it, but this is inevitable unless statistical tables and long descriptions of each condition are given. Therefore, one must be prepared for slight variations from the absolutely typical findings recorded here, but on the whole these are relatively rare, so that the writer may perhaps be forgiven for the approach that has been used.

\section{O R T HOP A E D I C S}

Postgraduate Medical Journal, July, 1952 PRICE $3 / 8$ POST FREE

THE MANAGEMENT OF SCOLIOSIS

J. I. P. James, M.S., F.R.C.S.

SOME CASES OF GOUT

David Levi, M.S., F.R.C.S.

ELECTROMYOGRAPHY OF THE ERECTOR SPINAE IN LOW BACK PAIN J. S. R. Golding, F.R.C.S.

A CASE OF SYNOVIAL CHONDROMATOSIS OF THE TEMPORO-MANDIBULAR JOINT David Trevor, M.S., F.R.C.S.

CASE REPORT-OSTEOGENIC SARCOMA OR OSTEOMYELITIS?

E. J. C. Wynne, M.B., B.Chir.

THE JUDET ARTHROPLASTY OF THE HIP VIA GIBSON'S LATERAL APPROACH

K. I. Nissen, F.R.C.S.

Published by

THE

FELLOWSHIP OF POSTGRAdUATE MEDICINE 60 Portland Place, London, W.I
CEREBRAL T UMOURS

(Postgraduate Medlcal Journal)

PRICE :

$2 / 9$

POST FREE

EDITORIAL: SIR VICTOR HORSLEY

THE PATHOLOGY OF INTRACRANIAL TUMOURS

Dorothy S. Russell, M.D. (Lond.), Sc.D. (Camb.). F.R.C.P. (Lond.)

VIRAL INFECTIONS OF THE HUMAN NERVOUS

Albert B. Sabin, M.D.

TUMOURS OF THE FRONTAL LOBE

Geoffrey Jefferson, M.S., F.R.C.S., F.R.C.P., F.R.S.

PITUITARY, PINEAL AND THIRD VENTRICLE TUMOURS Joe Pennybacker, M.D., F.R.C.S.

CEREBRAL ANGIOGRAPHY

J. W. D. Bull, M.A., M.D., M.R.C.P., D.M.R.

THE ORTHOPAEDIC REHABILITATION OF A PATIENT AFTER EXCISION OF A CEREBRAL TUMOUR

Wylie McKissock, O.B.E., M.S., and K. I. Nissen, F.R.C.S.

SPASTIC PARAPLEGIA IN MIDDLE AGE Colin Edwards, M.R.C.P.

Published by

THE FELOWSHIP OF

POSTGRADUATE MEDICINE

60, Portland Place, London, W.I

\section{RUTHIN CASTLE, NORTH WALES}

A Clinic for the diagnosis and treatment of Internal Diseases (except Mental or Infectious Diseases). The Clinic is provided with a staff of doctors, technicians and nurses.

The surroundings are beautiful. The climate is mild. There is central heating throughout. The annual rainfall is $\mathbf{3 0 . 5}$ inches, that is, less than the average for England.

The Fees are inclusive and vary according to the room occupied.

For particulars apply to THE SECRETARY, Ruthin Castle, North Wales. 